UDC 336.225.67:336.143

JEL classification: E62, H26, H30, 017

\section{Andrii ZOLKOVER}

PhD in Economics,

Doctoral Student,

Department of Business Economics and Tourism

Kyiv National University of Technologies and

Design, Ukraine

E-mail: zaaaaa@ukr.net

https://orcid.org/0000-0002-8176-1850

http://www.researcherid.com/rid/G-0000-2019

(C) Andrii Zolkover, 2019

\section{Received: 24.08.2019}

Revised: 27.09.2019

Accepted: 02.10.2019

Online publication date: 30.10 .2019

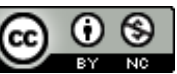

This is an Open Access article, distributed unde the terms of the Creative Commons AttributionNonCommercial 4.0 license, which permits unrestricted re-use, distribution, and reproduction in any medium, provided the original work is properly cited.
Andrii Zolkover (Ukraine)

\section{INSTITUTIONAL COMPONENT OF THE MECHANISM OF COUNTERING THE SHADOWING OF THE NATIONAL ECONOMY}

\begin{abstract}
Introduction. The level of shadowing of the economy in Ukraine remains one of the highest in the world and is a threat to its economic security and macroeconomic stability, investment attractiveness, etc. The dynamics of change in the main indicators of the functioning of the shadow economy indicates a low level of effectiveness of existing mechanisms to prevent the implementation of shadow operations. The existing institutional component of this mechanism does not fully form the preconditions for reducing the share of the shadow sector of the economy and therefore does not encourage businesses to withdraw their funds from the shadows. The high level of corruption and bureaucracy in the country has a negative impact on the efficiency of economic entities and thus creates the preconditions for the revision of existing instruments of state regulation of the economy.

Purpose. Research of efficiency of functioning of separate institutional components of the mechanism of counteraction to shadowing of national economy and definition of the most priority measures of prevention of the state by shadow schemes of withdrawal of incomes.

Results. The results of the study identified the main reasons for the high level of shadowing of the national economy, threats, and barriers to counteracting the participation of economic entities in the shadow schemes of capital withdrawal. The analysis of the main vectors of state influence on economic entities is carried out. Their efficiency has been evaluated. It is established that Ukraine occupies one of the last places in the world in the vast majority of indicators. Analysis of individual components of the indicator of ease of doing business in Ukraine showed a significant duration of procedures for reporting and payment of taxes, processing of documents for export/import, a significant cost of processing documents for export/import. The results of the study showed that one of the components that have a significant impact on economic entities is the high level of corruption in the country, low efficiency of corruption control procedures, low efficiency of government, etc. The necessity of development and application of a set of measures aimed at improving the quality of the institutional component of the mechanism of de-shadowing of the economy is proved.
\end{abstract}

Zolkover, A. (2019). Institutional component of the mechanism of countering the shadowing of the national economy. Economic analysis, 29 (3), 124-131.

DOI: https://doi.org/10.35774/econa2019.03.124

Keywords: institutional environment; level of corruption; efficiency of state regulation; rule of law; tax competitiveness; shadow economy. 


\section{Вступ}

Перманентне зростання рівня тінізації економіки в більшості країн світу створює передумови до більш ефективного формування та реалізації окремих складових політики детінізації економіки. На сьогодні найбільш гостро, як на національному так і на міжнародному рівнях, стоїть проблема ідентифікації найбільш ефективних та першочергових заходів протидії тіньовим операціям. На думку більшості науковців важливою складовою даних процесів виступає наявність ефективного інституційного інструментарію реалізації політики детінізації. Значні обсяги тіньового сектору економіки, що характерні для більшості країн 3 низьким та середнім рівнем розвитку, призвели до запровадження на інституційному рівні диверсифікованого інструментарію, що відрізняється направленістю, силою та характером впливу.

Наявність якісного інституційного середовища функціонування бізнесу слугує каталізатором зниження обсягів тіньових операцій за рахунок як реалізації обмежувальних та регулюючих заходів спрямованих на встановлення факту тіньової діяльності так і попередження ії реалізації [6].

Останніми роками в Україні і світі був запроваджений комплекс заходів, спрямованих на протидію тінізації: удосконалення системи фінансового моніторингу та контролю, реформування податкової системи, запровадження низки антикорупційних заходів. Реалізація даних заходів призвела до несуттєвого зниження рівня тінізації економіки (з 43\% ВВП у 2014 році до 30\% у 2018 році), але все рівно його значення залишається одним із найвищих у світі [7] та за оцінками більшості експертів все ще слугує загрозою економічній безпеці України та їі економічно сталого розвитку.

Вищезазначене формує передумови для оцінювання ефективності реалізації державою заходів детінізації національної економіки, визначення основних передумов низької їх результативності.

Емпіричне обґрунтування доцільності формування якісної інституційної складової механізму детінізації економіки як запоруки зниження обсягу тіньових операцій здійснене в наукових працях значної кількості вчених. У роботі І. Тютюник та Ю. Гуменної [9] обґрунтовано низький рівень ефективності заходів державного впливу на економічних суб'єктів з точки зору детінізації національної економіки.
А. Дрейгер та Ф. Шнайдер [3], С. Борлеа, М. Ахім та М. Мірон [1] у своїх роботах проаналізували вплив окремих елементів інституційної складової на ефективність реалізації державної політики детінізації економіки.

В цілому, більшість експертів наголошують на тому, то необхідною умовою подолання даного явища $€$ наявність комплексного підходу в основі якого лежить збалансування інституційної, економічної та нормативної складових механізму детінізації економіки. Актуальність даної роботи пояснюється відсутністю єдиного розуміння основних складових на які повинні бути спрямовані першочергові заходи держави в контексті детінізації національної економіки.

Проведений аналіз наукових напрацювань у даній сфері дозволив зробити висновок про відсутність комплексних досліджень причин низького рівня якості інституційного середовища реалізації державної політики детінізації економіки, механізмів та інструментів превенції держави реалізації тіньових схем.

\section{Мета статті}

Метою статті $\epsilon$ дослідження ефективності функціонування окремих інституційний складових механізму протидії тінізації національної економіки та визначення найбільш пріоритетних заходів превенції держави тіньовим схемам виведення доходів.

\section{Виклад основного матеріалу дослідження}

Якість інституційного середовища реалізації політики детінізації економіки може бути оцінена за допомогою двох методів: прямої та непрямої оцінки. Методи прямого оцінювання базуються на аналізі показників міжнародних рейтингів та результатів досліджень міжнародних організацій. Непрямі методи передбачають розрахунок показників функціонування економічної системи країни.

Одним із непрямих методів оцінювання якості інституційного середовища в країні $€$ вітчизняні методики оцінювання рівня тінізації та аналіз зміни даних показників в динаміці.

В Україні на сьогодні оцінювання рівня тінізації економіки здійснюється на основі Методичних рекомендацій, які включають наступні методи оцінювання: «витрати населення - роздрібний товарооборот», фінансовий, монетарний та електричний. За даними Міністерства економічного розвитку і торгівлі рівень тінізації економіки в Україні поступово знижується і за результатами 2018 року знаходився на рівні 30\% ВВП (рисунок 1). 


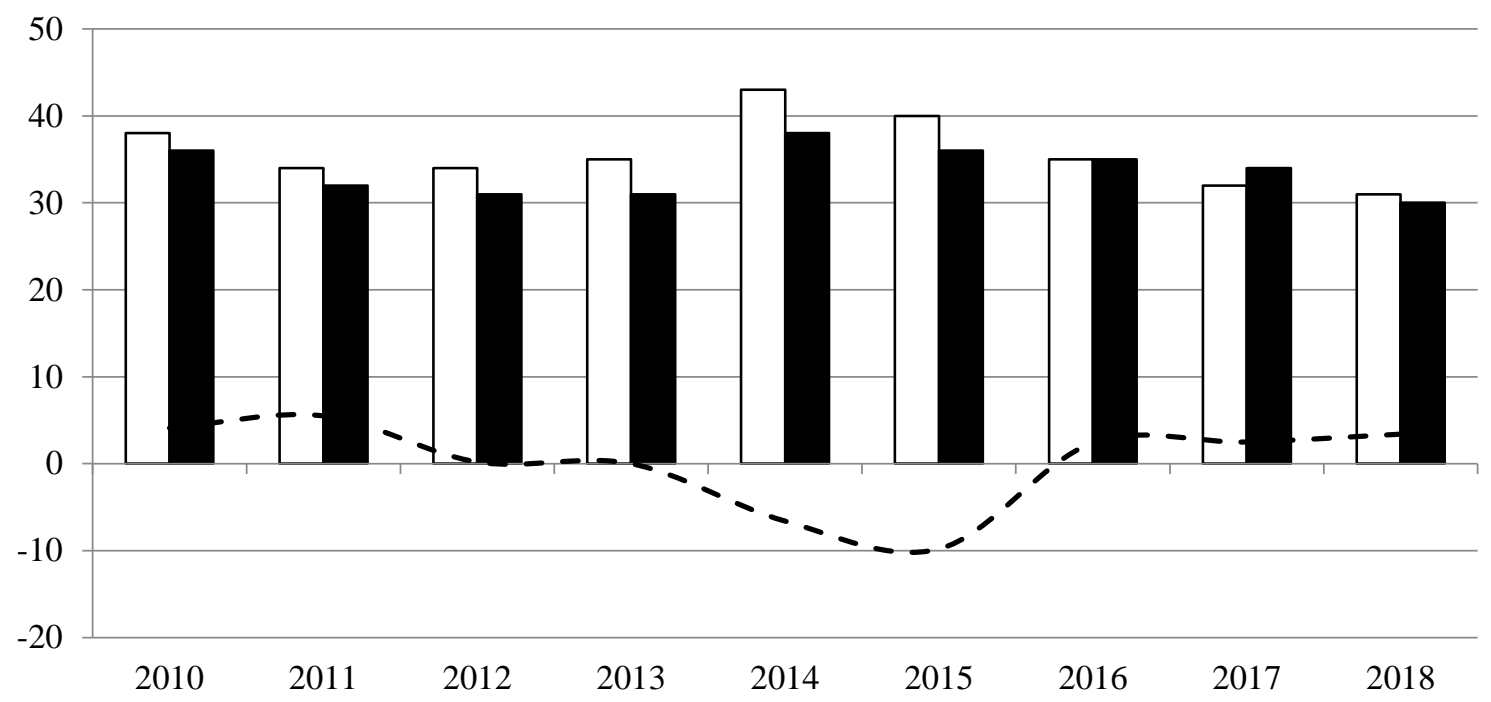

$\square$ Рівень тіньової економіки, \% до обсягу офіційного ВВП (на старою методологією)

Рівень тіньової економіки, \% до обсягу офіційного ВВП (на удосконаленою методологією)

- - - Зміна обсягу реального ВВП України, \% до відповідного періоду попереднього року

Рис. 1. Динаміка зміни рівня тіньової економіки в Україні за період 2010-2019 рр.

Джерело: побудовано на основі [8].

За період 2014-2018 рр., що визначалися кардинальними змінами податкової системи, заходами по боротьбі з корупцією і протидією тіньовому виведенню капіталу його значення знизилося лише на 8\%, що дозволяє зробити висновок про низький рівень ефективності розроблених заходів.

Одним із міжнародних індексів оцінювання якості інституційного середовища формування умов ведення бізнесу $€$ Індекс легкості ведення бізнесу (DoingBusiness), що узагальнює в собі наступні показники: організація бізнесу; отримання дозволів на будівництво; отримання електропостачання; реєстрація майна; отримання кредиту; захист прав інвесторів; сплата податків; міжнародна торгівля; забезпечення контрактів; закриття підприємства.

За показником легкості ведення бізнесу Україна займає 71 місце серед 190 можливих. За умови незначної кількості податкових платежів (5) час на підготовку податкової звітності $€$ одним із найбільших серед інших країн світу. Загальна ставка податку також перевищує середньосвітове значення. Враховуючи той факт, що за оцінками міжнародних експертів саме ставка оподаткування $\epsilon$ одним із вирішальних факторів, на користь переходу суб'єктів економічної діяльності в тінь, дані показники є стимулятори на шляху прийняття даних рішень. Дана ситуація $\epsilon$ результатом впливу сукупності об'єктивних та суб'єктивних факторів. Якщо об'єктивні фактори досить складно мінімізувати за короткий період часу, то вплив суб'єктивних факторів проявляється внаслідок існування бюрократичних процедур, високого рівня корупції, невиконання органами державної влади покладених на них функцій тощо.

Аналіз динаміки зміни рівня корупції в окремих країнах світу за період 2014-2018 рр. (рисунок 2) свідчать про негативні тенденції в Україні. Якщо у більшості аналізованих країн спостерігаються позитивні тенденції в даному напрямі, то в Україні темп зміни рівня інфляції постійно негативний. Найнижче значення рівня корупції мають Данія, Фінляндія, Люксембург та Німеччина, в той час як найвищі - Австрія, Чеська Республіка та Україна.

Дані тенденції $€$ результатами низької ефективності процедур контролю корупції, які за даними Світового банку в Україні $€$ найнижчими в світі. Якщо у більшості країн світу даний показник знаходиться на рівні 1,5-2,0, то в Україні якість контролю корупції складає -0,98, а отже відображає неефективність дій уряду та невідповідність фактичних результатів задекларованим цілям (рисунок 3). 
www.econa.org.ua

Таблиця 1. Показники легкості ведення бізнесу у 2017 році

\begin{tabular}{|l|c|c|c|c|}
\hline \multicolumn{1}{|c|}{ Показник } & Україна & $\begin{array}{c}\text { Європа та } \\
\text { Центральна } \\
\text { Азія }\end{array}$ & $\begin{array}{c}\text { Латинська Америка та } \\
\text { Карибський басейн }\end{array}$ & ОЕСР \\
\hline Кількість податкових платежів & 5,0 & 16,6 & 27,1 & 11,2 \\
\hline $\begin{array}{l}\text { Час на підготовку звітності та } \\
\text { сплату податків, годин/рік }\end{array}$ & 327,5 & 214,4 & 330,0 & 159,4 \\
\hline Загальна ставка податку & 41,7 & 32,3 & 46,7 & 39,8 \\
\hline $\begin{array}{l}\text { Час на прикордонний та митний } \\
\text { контроль при експорті/імпорті, } \\
\text { годин/рік }\end{array}$ & $6 / 32$ & $22,1 / 21,1$ & $61,9 / 62,6$ & $2,5 / 8,5$ \\
\hline $\begin{array}{l}\text { Час на оформлення документів } \\
\text { при експорті/імпорті, годин/рік }\end{array}$ & $66 / 96$ & $24,3 / 24,7$ & $52,5 / 79,1$ & $3 / 3,4$ \\
\hline $\begin{array}{l}\text { Вартість оформлення документів } \\
\text { при експорті/ імпорті, доларів } \\
\text { СшА }\end{array}$ & $192 / 162$ & $97,9 / 93,9$ & $110,4 / 116,3$ & $35,2 / 24,9$ \\
\hline $\begin{array}{l}\text { Вартість проходження контролю } \\
\text { при експорті/ імпорті, доларів } \\
\text { СшА }\end{array}$ & $75 / 100$ & $157,5 / 162,3$ & $529,7 / 647,2$ & $139,1 / 100,2$ \\
\hline
\end{tabular}

Джерело: побудовано автором на основі [2].

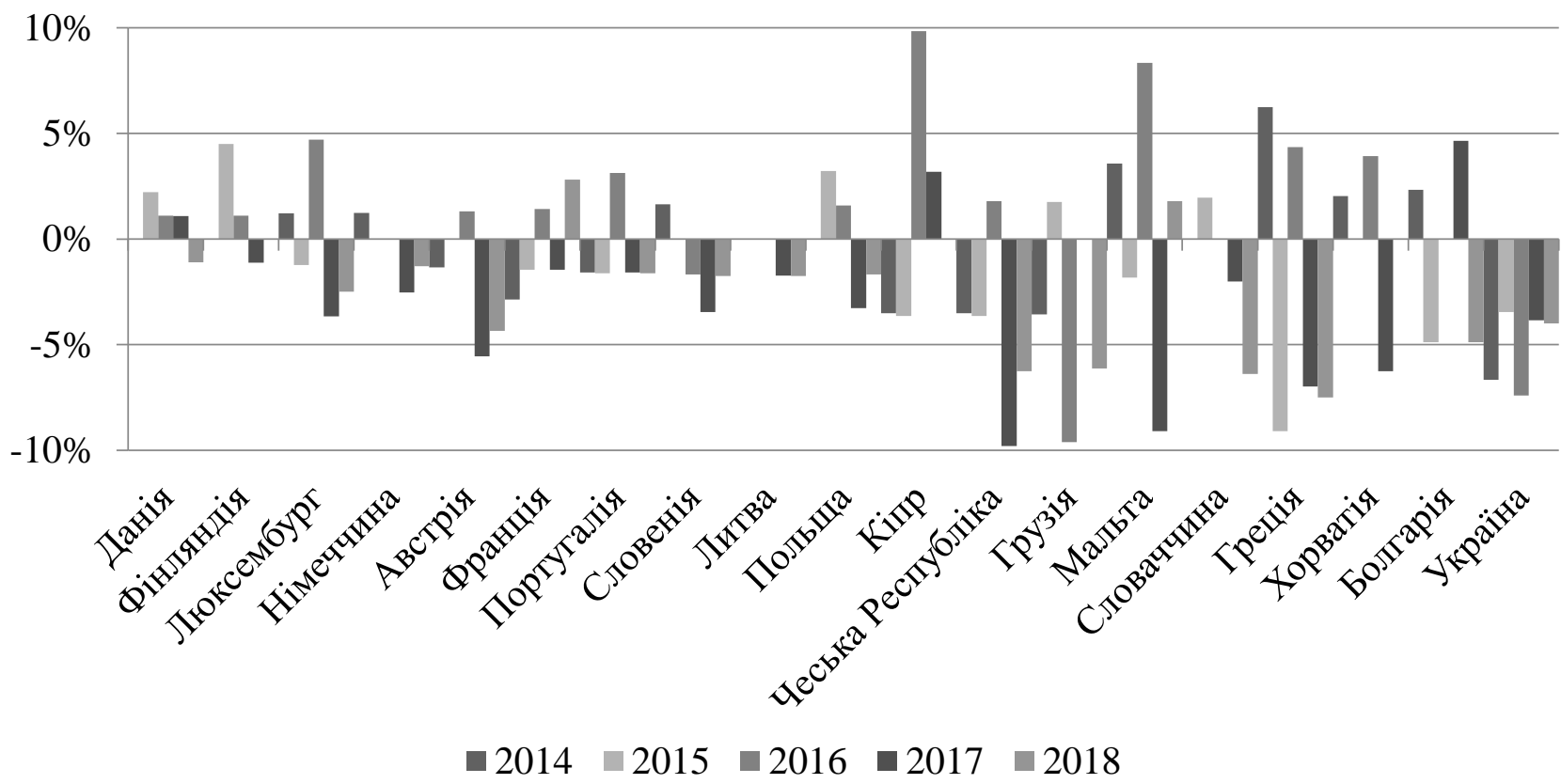

Рис. 2. Динаміка темпу зміни індексу сприяння корупції 2014-2018 роки

Джерело: систематизовано та побудовано на основі [5].

Функціонування бізнесу поза межами правового поля в умовах низької якості інституційного середовища значно спрощується, оскільки досить часто ініціаторами або безпосередніми учасниками тіньових схем виведення коштів стають самі представники державної влади. За цих умов суттєво знижується і ефективність процедур фінансового моніторингу та контролю. А отже реалізація будь-яких превентивних заходів спрямованих на превенцію тіньових операцій не приносить бажаного ефекту. 


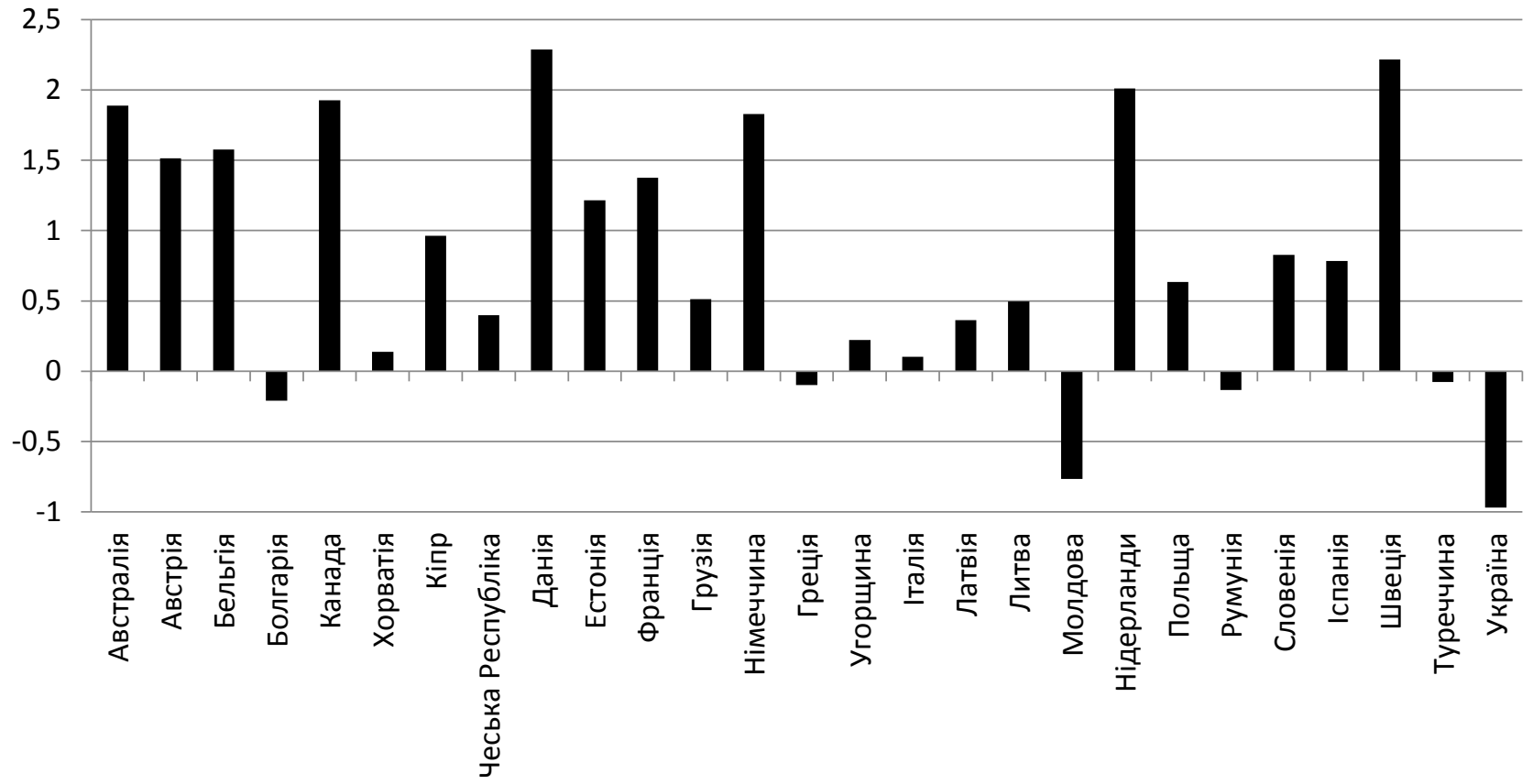

Рис. 3. Середнє значення якості контролю корупції в країнах світу за період 2010-2018 рр. [5]

Не менш важливими показником, що визначає вектори функціонування політики держави, швидкість імплементації задекларованих на міжнародному та вітчизняному рівнях програм та заходів $\epsilon$ індикатор ефективності уряду [4]. Одним із сучасних векторів розвитку економічної політки держави $€$ наближення ії до вимог міжнародної спільноти, узгодження нормативної бази 3 міжнародними нормами права, приведення їх у відповідність до сучасних особливостей функціонування економіки.

На сьогодні Україною на міжнародному рівні досить часто акцентується увага на пріоритетності реалізації політики протидії тіньовим операціям та легалізації незаконно одержаних коштів, боротьбою 3 корупцією, ухиленням від оподаткування тощо. Однак, як свідчать показники економічного та соціального розвитку країни дані пріоритети носять скоріше декларативний характер.

Однією із причин даної ситуації $€$ низька ефективність роботи уряду, як інституту влади відповідального за прийняття нормативної бази, що визначає та в подальшому регулює окремі вектори розвитку країни. За результатами порівняльного аналізу ефективності роботи уряду (рисунок 4) можна зробити висновок про його неефективну роботу.

За період 2010-2018 рр. Україна має один із найгірших показників ефективності уряду в світі, середнє значення якого складає $-0,55$, в той час як для більшості країн даний показник перевищує 1. Таким чином можна говорити не лише про низькі темпи роботи уряду а й про негативний характер його функціонування.

\section{Висновки та перспективи подальших розвідок}

Ефективна реалізація заходів держави щодо зменшення обсягів тіньових фінансових операцій можлива лише за умови узгодженої, збалансованої та якісної роботи всіх складових державної політики. Основою реалізації даних заходів $\epsilon$ наявність ефективного інституційного середовища функціонування бізнесу, що формує базис для його сталого та стабільного розвитку.

На сьогоднішній день, якість інституційної складової державної політики протидії тінізації знаходиться на критично низькому рівні. Більшість іï складових не відповідають міжнародним вимогам, не корелюють з потребами суспільства а отже не здатні виконувати покладені на них функції. В той же час, наявність значного рівня корупції в державних органах лише поглиблює дані процеси.

Вищезазначене обумовлює важливість удосконалення інституційної складової механізму тінізації економіки, перегляду найбільш пріоритетних напрямків державної політики та приведення їх у відповідність міжнародним вимогам. 


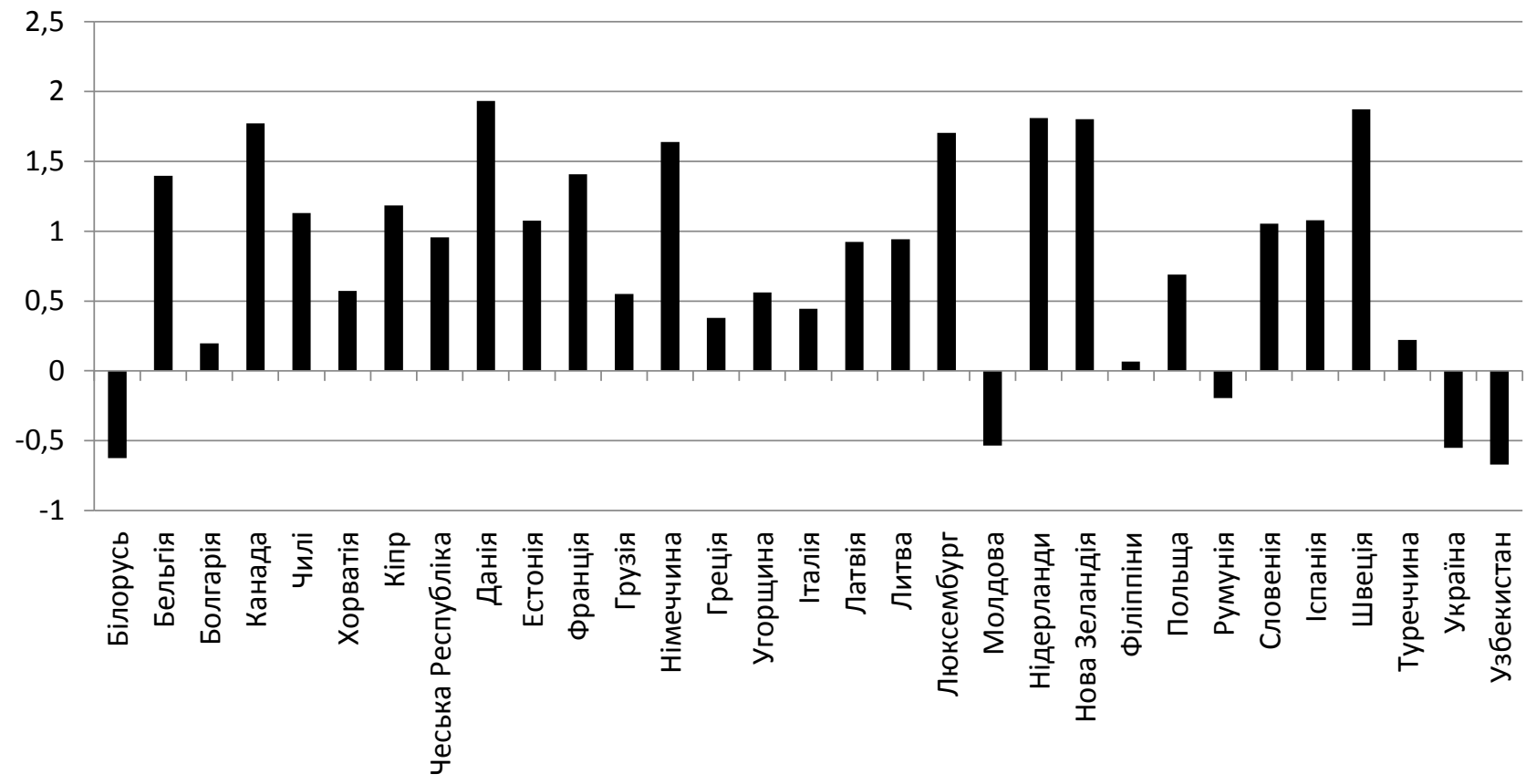

Рис. 4. Середнє значення індикатора ефективності уряду в країнах світу за період 2010-2018 рр. [5]

\section{СПИСОК ВИКОРИСТАНИХ ДЖЕРЕЛ}

1. Borlea S. N., Achim M. V., Miron M. G. Corruption, shadow economy and economic growth: An empirical survey across the European Union countries. Studia Universitatis "Vasile Goldis" Arad. Economics Seriesю. 2017. Vol. 27. Issue 2. P. 19-32.

2. Doing Business - 2017: Economy Rankings. World Bank Group. URL: http://www.doingbusiness.org/data /exploreeconomies/ukraine) (last accessed: 15.08.2019).

3. Dreher A., Schneider F. Corruption and the shadow economy: an empirical analysis. 2006. Retrieved from: http://ftp.iza.org/dp1936.pdf.

4. Terasawa K. L., Gates W. R. Relationships between government size and economic growth: Japan's government reforms and evidence from OECD. International public management journal. 1998. Vol. 1(2). P. 195-223.
5. World Development Indicators. URL: https://data.worldbank.org/indicato r?tab=all.

6. Карпенко І. В., Боронос В. Г. Моделювання макроекономічних індикаторів розвитку регіонів: оцінка рейтингу. Збірник тез доповідей 11-ї Всеукраїнської науково-практичної конференції «Статистична оцінка соціальноекономічного розвитку", 20 травня 2011 року. Хмельницький: Хмельницький університет управління та права, 2011. С. 143146.

7. Офіційний сайт Державної служби статистики. http://www.ukrstat.gov.ua.
8. Про затвердження Методичних рекомендацій щодо комплексної оцінки обсягів непродуктивного відпливу (вивезення) фінансових ресурсів за межі України : Наказ Міністерства економічного розвитку і торгівлі № 286 від 24.03.2015 p. URL: http://www.me.gov.ua/Ascod/List?| ang=uk-UA\&id=d6a26174-dOfd406b-9c30-

7a4043f04eb5\&tag=SistemaOblikuP ublichnoilnformatsii\&pageNumber= $86 \& f C t x=i n N a m e \& f S o r t=d a t e \& f S d i r$ $=$ asc.

9. Тютюник І. В., Гуменна Ю. Г. Тінізація фінансових потоків економічних суб'єктів: вартісний аспект. Причорноморські економічні студії. 2018. Випуск 33. С. 208-212.

10. Тютюник І. В., Решетняк Я. В. Фінансова децентралізація в Україні: можливості та загрози для забезпечення сталого розвитку територіальних громад. Економіка та держава, 2017. № 12. С. 43-47.

\section{REFERENCES}

1. Borlea, S. N., Achim, M. V., \& Miron, M. G. (2017). Corruption, shadow economy and economic growth: An empirical survey across the European Union countries. Studia Universitatis "Vasile Goldis" Arad. Economics Seriesю. Vol. 27. Issue 2. P. 19-32.
2. Doing Business - 2017: Economy Rankings (2017). World Bank Group Retrieved from: http://www.doingbusiness.org/data /exploreeconomies/ukraine.
3. Dreher, A., \& Schneider, F. (2006) Corruption and the shadow economy: an empirical analysis. Retrieved from: http://ftp.iza.org/dp1936.pdf. 
www.econa.org.ua

4. Terasawa K. L., \& Gates W. R. (1998). Relationships between government size and economic growth: Japan's government reforms and evidence from OECD. International public management journal.. Vol. 1(2). P. 195-223.

5. World Development Indicators. Retrieved from: https://data.worldbank.org/indicato r?tab=all.

6. Boronos, V. G. \& Karpenko, I. V (2011). Modeliuvannia makroekonomichnykh indykatoriv rozvytku rehioniv: otsinka reitynhu [Modeling of macroeconomic indicators of regional development: rating assessment] Zbirnyk tez dopovidei 11-yi Vseukrainskoi naukovo-praktychnoi konferentsii "Statystychna otsinka sotsialnoekonomichnoho rozvytku», 20 travnia 2011 roku. - Khmelnytskyi: Khmelnytskyi universytet upravlinnia ta prava. P. 143-146.
7. Ofitsiynyy sayt Derzhavnoyi sluzhby statystyky. (2018). Retrieved from http://www.ukrstat.gov.ua. [in Ukrainian].

8. Pro zatverdzhennia Metodychnykh rekomendatsii shchodo kompleksnoi otsinky obsiahiv neproduktyvnoho vidplyvu (vyvezennia) finansovykh resursiv za mezhi Ukrainy : Nakaz Ministerstva ekonomichnoho rozvytku i torhivli № 286 vid 24.03.2015 r. [On approval of Methodical recommendations for a comprehensive assessment of the volume of unproductive outflow (export) of financial resources outside Ukraine: Order of the Ministry of Economic Development and Trade № 286 of 24.03.2015] Retrieved from: http://www.me.gov.ua/Ascod/List?| ang=uk-UA\&id=d6a26174-dOfd406b-9c30-

7a4043f04eb5\&tag=SistemaOblikuP ublichnoilnformatsii\&pageNumber= 86\&fCtx=inName\&fSort=date\&fSdir =asc. [in Ukrainian].
9. Tiutiunyk, I. V., \& Humenna, Yu. G. (2018). Tinizatsiia finansovykh potokiv ekonomichnykh subiektiv: vartisnyi aspekt. [Shading of financial flows of economic entities: cost aspect]. Black Sea Economic Studies, 33, 208-212. [in Ukrainian].

10. Tiutiunyk, I. V., \& Reshetnyak, Ya. V. (2017). Finansova detsentralizatsiia v Ukraini: mozhlyvosti ta zahrozy dlia zabezpechennia staloho rozvytku terytorialnykh hromad [Financial decentralization in Ukraine: opportunities and threats to ensure sustainable development of territorial communities]. Economy and State. Vol. 12. P. 4347. [in Ukrainian]. 